\title{
The Aesthetic Gaze: Siting Nineteenth Century Indian Travel Writing
}

\author{
Avishek Ray \\ Assistant Professor, Department of Humanities \& Social Sciences, National Institute of \\ Technology Silchar, Silchar, Cachar, Assam. Email: avishek.avishek@gmail.com
}

Received October 19, 2016; Revised December 24, 2016; Accepted December 30, 2016; Published January 14, 2017

\begin{abstract}
Indians have reportedly been traveling to Europe since the seventeenth century and narrativizing their travel accounts at least since the mid-eighteenth century. However, 'travelogue', what we know by European standards, as a genre in the Indian context is intrinsically linked with colonial exposure, the literary 'modernity' that purportedly ushered thereafter, and the high noon of Indian nationalism. Citing late nineteenth and early twentieth century 'Indian' travelogues, this paper examines the stakes in the Indian travelers emulating the eighteenth century Grand Tourist, and demonstrates how the literary articulation of tourism therein is symptomatic of an elitist-exclusionary mindset that strived to showcase cultural proximity with the colonizer on the one hand, while distantiating the colonially un(der)exposed 'natives' on the other hand.
\end{abstract}

Keywords: Indian travelogue, nineteenth century, colonial modernity, British India, aesthetic gaze

\section{Introduction}

With the shift away from Calcutta being an ordinary port town to an urbanized commercial city in the nineteenth century, the bhadralok (gentry) class emerged as the future patrons of tourism. However, the intention here is not to say that the 'modern' Bengalis started to travel after the colonial exposure, but when one uses 'tourism', as opposed to travel, what is hinted at is an inculcated mentality towards traveling that would for the first time render possible the cultural polarity between the 'good traveler' and the 'bad traveler', a mode of traveling to be consented to and another to be refuted. Tourism is an industry - 'predominantly capitalistically organised' in order to maximize the 'political economy of the social construction of 'reality' and social construction of place' (Britton, 1991, p. 475) - whereby all possible practices of mobility is increasingly rendered marketable through commercial standardization.

In 1865 Thomas Cook, banking on his experience of having organized a number of railway excursions in the 1840 os and personally guided a few Continental Tours in the 1850s, opens a shop in Fleet Street, London. This officialized Cook's professionalization as a travel agent, which would remain unrivaled in the (guided) tourism industry for decades to follow. In the year Cook organizes and leads his first round-the-world tour (1872-73), Maharaja Jagatjit Singh (1872-1949) would be born in India. The reason I dramatize Singh's birth is that he would soon be Cook's client, and possibly the first Indian to be so. George Routledge and Co. (now Routledge) published Singh's travelogue in 1895. This was Singh's travel account from his trip to Europe in 1893. This implies that

(c) AesthetixMS 2016. This Open Access article is published under a Creative Commons Attribution Non-Commercial 4.0 International License (http://creativecommons.org/licenses/by-nc/4.o/), which permits non-commercial re-use, distribution, and reproduction in any medium, provided the original work is properly cited. For citation use the DOI. For commercial re-use, please contact editor@rupkatha.com. 
Singh got in touch with Cook when he and the world's first travel agent was barely twenty years old ${ }^{\mathrm{i}}$. Of course, Singh was no ordinary man (for he was a Rajah); he was not a Bengali either. Yet, one needs to underline this nexus as a model for emergent 'structure of feeling' towards traveling.

\section{Siting Pedagogic Concerns within Colonial Modernity}

MacCannell (1976) sees tourism as grappling with the 'authentic other' - an 'imagined' authenticity, understandably exoticized in the Orientalist gaze, that has disappeared from the post-industrial 'disenchanted' world, more appropriately from the increasing mundaneness of the everyday life. Graburn (1983) argues that tourism is a practice of liminality: a temporary escape from the hereand-now till the restoration of the subject, what in the Deleuzean view, could be seen as the phase between deterritorialization and reterritorialization ${ }^{i i}$. Nuemann $(1988$, p. 22) in saying: 'Tourism is a metaphor of our struggle to make sense of our self and the world within a highly differentiated culture', already assumes an oppositional relation between the tourist and the toured. Be it the sixteenth century Renaissance 'discoverer' or the nineteenth century anthropologist or even the colonial subject 'writing back' to the empire, tourism indeed is the strive to self-assert one's Self over the Other. However, for the racialized colonial subject, the process of self-assertion was not only limited to the dichotomy between the Self and the Other, but involved a second-order differentiation: first, from the colonized; second, from the subalterns at the periphery of nationalist politics.

The colonizers had barricaded themselves from the colonized by an 'arbitrary' but 'universal practice of designating...a familiar space which is 'ours' and an unfamiliar beyond 'ours' which is 'theirs"(Said, 1978, p. 54). Now, the bourgeoisie elites, spearheading the nationalist politics but outpowered in the overwhelmingly racist 'outer domain', shored up as the 'you': the intermediary between the deictic categories 'we' and 'they' (Chatterjee, 1997). 'You' first had to distinguish themselves as 'modern-progressive' from 'they', next from 'we' in order to re-acquire his lost dignity $^{\text {iii }}$, the former being the prerequisite for the latter. In a desperate attempt to buttress their disempowerment, 'you' casted its identity against 'they' in the same way 'we' did upon 'you'. This paper demonstrates how tourism and practices of traveling (among other things) in the nineteenth century functioned as a symbolic site for reinscribing the dynamics of social mobility on the weyou-they tripartite scale.

With the opening of the Suez Canal in 1869 more Indians would set sail to Europe than ever before, albeit people from India reportedly traveled to Europe since the seventeenth century. While travel narratives were increasingly recorded by these Indians at least since the mid-eighteenth century, those were generically not quite the same as the 'travelogue' by the European standards ${ }^{\text {iv }}$. As of the Bengali context, Mukhopadhyay (2002, p. 298) reminds:

It is remarkable that at least three illustrious Bengalis - Dwarakanath Tagore, Rammohan Roy and Michael Madhusudan Dutt - had been to Europe before the 1870 . Yet, none of them wrote a travelogue. Thus, travel per se was not the cause of the rise of travelogue as a genre in Bengali. What was instrumental in its rise was something else: the development of vernacular prose and the four basic genres that help express the modern self: novel, biography, autobiography, and diary. We can postulate that the rise of the modern travelogue in Bengali was part and parcel of the project of fashioning a 'modern' Bengali self.

Flourishing during the high noon of Bengali nationalism, the nineteenth century travelogues would differ generically from their 'pre-modern' counterparts in terms of their mode of addressal, tonality of self-expression etc. (Sen, 2005; Mukhopadhyay, 2002; Chatterjee, 1998). While the eighteenth 
century travel narratives had been exploratory-curious in nature, naively expressive of an immanent sense of awe and wonder about anything Western; the ones in the nineteenth century and beyond were all educative ${ }^{\mathrm{v}}$. The nineteenth century Bengali bhadralok -- fervently obsessed to fashion himself as 'modern' and showcase cultural compatriotism with the colonizer, his tastes and customs -were culturally familiarized with (the idea of) Europe, and hence 'disenchanted' when narrating their travel.

For that matter, the eighteenth century travelers, at least those whose travelogues are on records, were all educated; in fact, over-educated to the degree that some traveled as personal tutors to the British expats ${ }^{\mathrm{vi}}$. But, it is, in effect, the impact of Macaulay's educational policy 'implanting' the perception of Europe(an-ness) on the mental terrain of its recipients that constituted the main difference. As Chatterjee (1998, p. 1334) puts it:

The voyage acquires for him the moral significance of a rite of passage. Not everything he would see in England would necessarily meet with his approval...But overall, he would have no doubt that what he was experiencing, and what he would need to convey to his countrymen back home, was a moral and civilisational essence, expressed in such virtues of the modern English people as the spirit of independence, self-respect and discipline, their love for art, literature and sport, and above all, their cultivation of knowledge.

In other words, as his gaze towards Europe, and more generally speaking, towards the act of traveling, was already contrived by and within the parameters of Western pedagogy, the nineteenth century traveler's will-to-travel was motivated more by pedagogical concerns than the euphoria of 'discovery'.

\section{The Motif of the Eye}

This pedagogic concern manifested itself in what Kosambi (1962) calls 'creative introspection' -- the tendency to weigh everything against epistemic paradigms set forth by the West --, which attested to the 'modern' traveler's (cultural) proximity with and affinity to the colonizer ${ }^{\text {vii }}$. The legacy of the European Grand Tour(ist) had continued triumphantly in the eighteenth century through the sojourns of the propertied bourgeoisie class. DeBolla (2003) shows how the eighteenth century culture(s) of visuality had given rise to the practice of apprenticeship of one's ocular sensibility what he calls 'the education of the eye' - meant to testify one's assertion to aristocratic inheritance of taste, to acquire an appreciation for the 'high' culture, to certify him as an aesthete. Diametrically opposite to what the Romantics meant by 'wanderlust' (though some of them in reality continued to undertake travels of the kind I am talking about), the idea of travel seemed to be all about how a bunch of elites is seen to have seen canonical sites rather than secularized sights ${ }^{\text {viii }}$. By the nineteenth century, the genre of travelogues as a whole by the Bengalis ${ }^{\mathrm{ix}}$, needless to say, educated upper-class Hindu elite males, reveal to have completely internalized the trope of itinerarized travel(ing), one that comes with pre-conceived tailor-made maps: geographical in terms of what is worth 'seeing', but more importantly pedagogical in terms of how and to what extent it would contribute to the traveler's spectatorial credibility, aesthetic connoisseurship, elevated personhood and so on because all of these virtually counted towards the possibility of the disempowered subject's upward mobility in the we-you-they tripartite equation.

This explains the dominant recurrence of the motif of the 'eye' and vision in the contemporary (Indian) travelogues. Instead of merely narrativizing travel expeditions, the travelogues were as though an emblem of achieving visual literacy, an ocular modernity, acquired only by dint of certain 'ways of seeing'. For Ramakrishna (1912, p. 1) '[t]o visit England was the dream of 
my (his) life'. He says to have 'witnessed' speeches in the (British) Parliament. Likewise, Jagatjit Singh's 'great ambition to travel in Western countries' is finally satiated with his arrival in Europe, when he explains: 'I have seen something of the world outside India' (1893: iii). Mukharji (1889: 330) takes pride in assuming that he 'saw things which no Indian remaining in his own country can hope to see, ...in the atmosphere of England which opens the eyes and widens the mind'. The incipit of 'babu' Bholanauth Chunder's narrative is an epigraph from Horace Walpole: 'If any man would keep a faithful account of what he had seen and heard himself, it must, in whatever hands prove an interesting thing' (1869 [I]: 1). On the same note, a British expat serving as an editor and professor in thenMadras (now Chennai), J. Talboys Wheeler introduces his travelogue as: 'the genuine bona fide work...(that) looked upon every scene with Hindoo eyes, and indulged in trains of thought and association which only find expression in Native society, and are wholly foreign to European ideas' (Chunder, 1869: xii). It is not without a reason that the idea of 'sight-seeing' comes as a rider to mind the moment we say 'tourism'.

\section{The Aesthetic Gaze}

While problematizing the foundations of Cartesian subjectivity, Marleau-Ponty (2007, p. 354, 367) uses the conduit of the ocular self:

Immersed in the visible by his body, itself visible, the seer does not appropriate what he sees; he merely approaches it by means of the gaze, he opens onto the world I do not see it according to its exterior envelope; I live it from the inside; I am immersed in it.

Inasmuch as when touching something, one touches and is being touched simultaneously; during see-ing (which is a process rather than a state) one sees and perceives herself as having seen at the same time. Likewise, the 'tourist' sees and knows about what he sees on the one hand; but on the other he now perceives himself as having known, and therefore feel elevated. It is this ocular self of the 'tourist' - arisen exponentially out of seeing what he sees, seeing been seen, seeing his 'seeing' being validated by the colonizer's pan-optic gaze - that reinforces the hierarchical difference between the seer and the seen, the spectator and the spectacle.

The spectator, for Ranciere (2010), is a paradoxical figure. He effeminizes the spectator for she is ignorant, docile and passive; yet no spectacle is complete without it been viewed. The 'ignorant' spectator does not have the 'authentic' knowledge to interpret the spectacle, all she does is 'to venture into the forest of things and signs, to say what they have seen and what they think of what they have seen, to verify it and have it verified' (2010, p. 12). The politics of the travelers' scopophilic desire has to be understood in the broader context of the nineteenth century thrust in a myriad of Realist modes of representations including photography. While reformers 'back home' were making a case for a radical revision of the 'faulty' systems of existing 'Indian' curriculum to be more 'modern' -often understood as synonymous to empirical -- and at par with the European standards ${ }^{\mathrm{x}}$, these travelers were increasingly fashioning themselves after the classic figure of the European Grand Tourist, whose tours supplemented the Lockean tabula rasa thesis. One's 'eye', in this scheme, is not only the instrument to ascend to the pinnacle of empirical knowledge but also instrumental in determining the 'I', because what one sees and how she sees determine the class and rank of its possessor. For the ideal nineteenth century traveler, tourism therefore is as though, again to borrow Chatterjee's (1998, p. 1334) phrase, that 'rite of passage' from being 'ignorant' to becoming 'emancipated'.

What characterizes this emancipatory interest is a highly contingent classist undercurrent. The elitist ideology immanent in the tourist's 'aesthetic gaze' (Bourdieu, 1984) contributes to the heuristic construction of the 'tourist' as an emancipated subject, and in so doing, renders possible 
the hierarchy between the tourist and the toured. 'Problems are and will be there all the times, people are born to think and work on those. Why should an artist snatch their work? Why should an artist carry the burden?', writes Ray (1973, p. 45), evidently conscious of his image of an elitist pioneering literary practitioner. He distinguishes between the 'people' and the 'artist' - each with separate assignments and no overlaps, in a fashion reminiscent of Theophile Gautier's ideals - based on an 'imagined' notion of (self-)enculturation. This reflection of Ray's can actually be read as a testimony to how the 'dominant aesthetics' of nineteenth century colonial modernity, to borrow Bourdieu's (1984) evocative phrases, fostered 'class fractions', unfolding within the discourse of elitistenclavist ideologies. Indeed, the classist, and often racist, tinge of this travelogues -- consider, Mukharji (1889, p. 324) being reminded of Indian 'savagery' in the contrasting grandeur of the British museums, or Bholanauth Chunder (1869 [II], p. 182) tracing the lineage of Santhal to the Dasyas and the Asuras -- had completely internalized the imperialist tropes so frequently used in the novels, by Conrad, Foster and suchlike, which groomed and nurtured the (literary) tastes of the bhadralok class.

\section{Conclusion}

Taking cues from Sen's (2005, p. 13) observation -- the nineteenth century Bengali travelers who had once perceived themselves 'as an inferior Other of Europe and strove to distance and differentiate from it' --, one may contend here that in order to 'differentiate' they had to first demonstrate that they had acquired the repertoire to be able to 'differentiate from it'. And, in order to demonstrate that they had acquired the repertoire they had to 'integrate with it' to a certain degree. Differentiation arises from comparison, and comparison is based on difference-in-identity. In order for an apple to be differentiable from an orange, first we have to acknowledge that both are homologous entities: they belong to the same genus, which is to say, fruits. Likewise, 'you' must attain comparability with 'we' prior to be differentiable. Traveling practices are one of many domains 'you' sought to be like 'we', out of 'the desire for a reformed, recognizable Other, as a subject of a difference that is almost the same, but not quite' (Bhabha, 1994, p. 85). Thus the model of the Grand Tourist set the paradigm for traveling, whereby the 'traveler' ought to render himself to 'emancipation', in other words, his 'will to travel' ought to come from 'will to know'. Born out of this 'will to know' was however a regulatory and exclusionary intent to segregate the 'native' subalterns, based upon which the imperialist-classist affiliation of the ideal 'traveler' would be hallmarked.

With 'his wonderful familiarity with English ideas and turns of thought, which could only have been obtained by an extensive course of English reading' (1869 [I], p. xi), Chunder traveled and produced what James Talboys Wheeler testifies to be 'a survey of India with the eyes of a Hindoo' (1869 [I], p. xii). While on the one hand, Chunder wins endorsement from an eminent bureaucrathistorian of the British Raj, on the other hand, barely two years after the publication of Chunder's account, the British would deploy the Criminal Tribes Act (1871) that held the nomadic tribes and the peripatetic communities 'inherently criminal' and was keen to 'scientifically' determine the correlation between 'nomadicity' and criminality ${ }^{\mathrm{xi}}$. Chunder's travel is being eloquently appraised, while certain communities, already 'nomadic', are being forced to sedentarize. This paradox is symptomatic of what was at stake in the nineteenth century 'modern' traveling practices. The 'modern' perception 'of the journey itself as an education, as a civilizing and cultivating process, implied its systematization as a curriculum' (Leed, 1991, p. 185) characterizes the extent of instrumentality imbibed by the nineteenth century travelers from having been exposed to colonial modernity, and his hankering for aesthetic connoisseurship. 


\section{Notes}

${ }^{\mathrm{i}}$ For a cursory glance on the landmark dates/events in the history of Thomas Cook, see their website < http://www.thomascookgroup.com/history>; last visited on 14 October 2016. Singh (1895, p. 2) acknowledges that his trip in 1893 had been arranged by Thomas Cook.

ii This explains the idea behind the coinage of 'excursion': a certain kind of touring-habit being known as excursion. The Oxford English Dictionary cites 'excursion' to have meant 'deviation from a definite path or course', 'deviation from custom, rule, or property' in its 17-18th century usages.

iii I deliberately use 'his' here keeping in mind the masculinist historiography of colonial politics. For detailed discussion on the women's question in Indian nationalist politics, see Sarkar (2001, pp. 23-52), Sangari et al. (1989) and Chatterjee (1997, pp. 116-57).

iv When I say 'travelogue', I hint at its colonial undertone. The word 'travelogue' comes from the words 'travel' and 'logue' (<logos); and is intrinsically tied to the idea of colonial expansion. Bassnett (1993, pp. 92-114) demonstrates how in the colonial context the newly explored lands in the European travelogues has been termed 'virgin', figuratively indicating passivity and barrenness that needs to be harnessed by penetrating and fertilizing them. In narrativizing how other cultures function as sign-systems, the 'travel writers constantly position themselves in relation to their point of origin in a culture and the context they are describing'; and the logocentricism involved therein reflects 'how prejudices, stereotypes and negative perceptions of other cultures can be handed down through generations' (p. 99). As a genre been validated and popularized by colonial expansion, 'travelogue' thus always reinscribes the traveler's ethnic affiliation. This was not explicit in the 'pre-modern' Indian travel narratives. Take for example the genre of the Safarnama of Arabic-Persian origin, or the genre of quasi-fictitious Samdesa Kavya in the Sanskritic tradition; these are merely descriptivist narratives. This is however not to say that the latter were 'objective' or 'unprejudiced'; but my point is to emphasize the difference in degree of explicitness in self-identity-building rhetoric in the 'travelogue' and that in the 'pre- modern' Indian genres of travel narratives.

${ }^{v}$ Sen (2005, p. 30) and Chatterjee (1998, p. 1334), for example, recount how euphoric Mirza Shaikh Ictisam al-Din -- an 18th century traveler who knew fairly well about Indian navigational technologies -- was when narrating his 'discovery' of how a compass works.

${ }^{v i}$ Of six such travelers who had travel narratives published to their credit by the end of the 18th century, Mirza Shaikh Ictisam al-Din (also spelled as Mirza Shaikh Ihtisamuddin, 1730-180o) traveled to Europe during 1766-68 to lend his expertise on Persian diplomacy to Captain Archibald Swinton, an East-India Company employee-turned-European diplomat; Munshi Isma'il traveled to Europe during 1771-73 as a Persian language teacher to Claud Russell, the British diplomat; Mir Muhammad Husain ibn Abdul Azim Isfahani (d. 1790) during 1775-76 as a Persian language teacher to some Mr. Elliot; while Mirza Abu Talib Khan Isfahani (1752-1806) is known to have traveled to England during 1799-1802 in pursuit of knowledge. For a brief biography of the six travelers and the nature and contents of their 'travelogues', see Fisher (2007).

${ }^{\text {vii }}$ For example, consider Trailokyanath Mukharji's (1889, p. 134, 135) observation in this context: 'The European knows more of our mountains and rivers than we do: he knows more of the plants that grow around us, their names, their properties, even the size and shapes of their leaves; he knows more of what is interred in the bosom of our earth; he knows more about the capabilities of our land; in everything he knows more than we do of our own country. Then he knows better how to use that knowledge for the benefit of men. We do not know these things; hence we are "natives".

viii I thank Ian McLachlan to have alerted me to the playfulness in the pair of words: site and sight. And, 'secular', the way I use here, has got no religious connotation; but suggests that unevaluated, yet-to-beappreciated state of the 'sight', which when canonized becomes a 'site'.

${ }^{\text {ix }}$ I am abstaining from saying 'Bangla travelogues because some wrote in English. 
${ }^{\mathrm{x}}$ The nineteenth century debate on educational reforms was contested by the Orientalists, who were in favor of the 'traditional' pedagogy; and the Anglicists, who were in favor of an entirely English system focused on the Natural sciences, based on empiricism. For the latter group, 'scientific knowledge', viewed as integral to Western culture, was the most important modernizing force and the reason behind the Western civilizational 'progress'. Rammohun Roy and Iswarchandra Vidyasagar, two prominent Bengali ideologues of reformation, for instance, latched their demand for 'modern' curricula on what they perceived as the 'fallibility' of the Indian knowledge systems. For a quick reference, see Roy's (1885, p. 471, 472, 473) famous letter dated 11 December, 1823 to Lord Amherst, and parts of Vidyasagar's 'notes' dated 12 April, 1852 on the Sanskrit College, cited in Bandyopadhyay (2001,p. 23).

${ }^{x i}$ For details on the Criminal Tribes Act (1871) and its implication on the socially 'backward' peripatetic communities in British India, see Nigam (1990a, 1990b) and Mayaram (2003: 13-35).

\section{References}

\section{P R I N T}

Bandyopadhyay, D. (2001). Anekanta Sahityatatta (Multiple Discourses in Literary Theory), Kolkata: Alochanachakra

Bassnett, S. (1993). 'Constructing Cultures: The Politics of Travellers' Tales', in Comparative Literature: A Critical Introduction, Oxford: Wiley

Bhabha, H. (1994). 'Of Mimicry and Man: The Ambivalence of Colonial Discourse', in The Location of Culture, London and NY: Routledge. 85-92

Bourdieu, P., 1984. Distinction, London: Routledge

Britton, S. (1991). 'Tourism, capital and place: towards a critical geography of tourism', in Environment an Planning: Society and Space, Vol. 9, pp. 451-78

Chatterjee, P. (1997). The Nation and Its Fragments: Colonial and Postcolonial Histories, Delhi: Oxford University Press 1998. 'Hundred Years of Fear and Love', in Economic and political Weekly, Vol. 33: 22, pp. 1330-36

DeBolla, Peter. (2003). The Education of the Eye, Stanford: Stanford University Press

Fisher, Michael H. (2007). 'From India to England and Back: Early Indian Travel Narratives for Indian', in Huntington Library Quarterly, Vol. 70, No. 1 (March 2007), pp. 153-172

Graburn, N. (1983). 'The anthropology of tourism' in Annals of Tourism Research, 19: 9-33

Kosambi, D.D. (1962). Myth and Reality: Studies in the Formation of Indian Culture, Bombay: Popular Prakashan

Leed, Eric J. (1991). The Mind of the Traveler: From Gilgamesh to Global Tourism, New York: Basic Books

MacCannell, D. (1976). The Tourist: A New Theory of The Leisure Class, London: Macmillian

Marleau-Ponty, M. (2007). The Marleau-Ponty Reader (Edited by Ted Toadvine \& Leonard Lawlor), Illinois: NorthWestern University Press

Mayaram, Shail. (2003). Against History, Against State: Counterperspectives from the Margins, NY: Columbia University Press

Mukhopadhyay, B. (2002). 'Writing Home, Writing Travel: The Poetics and Politics of Dwelling in Bengali Modernity', in Comparative Studies in Society and History, Vol. 44, No. 2 (April 2002), pp. 293-318

Nigam, S. (1990a). 'Disciplining and policing the 'criminals by birth', Part I: The Making of a Colonial Stereotype - The Criminal Tribes and Castes of North India', in Indian Economic E Social History Review, Vol. 27: 2, pp. 131-64 (1990b). 'Disciplining and policing the 'criminals by birth', Part 2: The development of a disciplinary system, 1871-1900, in Indian Economic \& Social History Review, Vol. 27: 3, pp. 257-87

Nuemann, M. (1988). 'Wandering through the museum: experience and identity in a spectator culture', in Border/Lines, Summer, pp. 19-27

Ramkrishna, T. (1915). My Visit to the West, London: Unwin 
Ranciere, J. (2010). The Emancipated Spectator, London: Verso Ray, A. (1973). Pathe Prabase (On Road and Exile), Kolkata: Mitra O Ghosh Said, Edward. (1978). Orientalism, London: Routledge and Kegan Paul Sangari, K. et al., (1989). Recasting Women: Essays In Indian Colonial History, Delhi: Kali for Women Sarkar, Tanika. (2001). Hindu Wife, Hindu Nation, Delhi: Permanent Black

Sen, Simonti. (2005). Travels to Europe: Self and Other in Bengali Travel Narratives 1870-1910, Delhi: Orient Blackswan

Singh, J. (1895). My Travels in Europe and America 1893, London: G. Routledge \& Sons

O N L I N E

Chunder, Bholanauth. (1869). The Travels of a Hindoo to various parts of Bengal and Upper India, Vol. 1 \& 2, London: N. Trubner. Web. 12 June 2015. <Google Books>

Macaulay's Minute on Indian Education. Document dated 2 February 1835. Web. 12 June 2015. $<$ http://goo.gl/sYGUPb >

Mukharji, Trailakynath. (1889). A Visit to Europe, Calcutta: W. Newman \& Co. Web. 12 June 2015. $<$ Google Books $>$

Roy, Rammohun. (1885). The English Works of Raja Rammohun Roy, Calcutta: Oriental Press. Web. 12 June 2015. <Google Books> 